\title{
IMPACTS OF THE ARAB SPRING ON TRADE IN AIRLINE SERVICES
}

\author{
Kenneth Button \\ George Mason University, USA \\ Gianmaria Martini, \\ University of Bergamo, Italy \\ Davide Scotti \\ University of Brescia, Italy
}

Corresponding author details:

Kenneth Button, University Professor, School of Policy, Government and International Affairs, George Mason University (MSN 3B1), 3351 Fairfax Drive, Arlington, VA 22201, USA. Email: Kbutton@gmu.edu

\begin{abstract}
This paper examines the impacts of the "Arab Spring" on trade in air services between the various North African and Levant countries involved. Studies of the implications of these socio-economic changes on trade in the region are made difficult because of a paucity of good economic data and the involvement of outside countries in the trade that now takes place. The number of international airline seats available provides a partial and fairly reliable variable to examine trade patterns. The analysis looks at changes in patterns of trade in these services between 1997 and 2013.
\end{abstract}

Acknowledgement: This paper was completed while Kenneth Button was a visiting professor at the University of Bergamo.

Key Words: Arab Spring, airlines, international trade, political instability

Running title: Airline services and the Arab Spring

Words in text (including footnotes): 2029 


\section{Introduction.}

The Arab Spring that began in late 2010 brought considerable political change to nations in the Middle East and North Africa (the MENA region). The economic reasons for the timing of these changes is not always clear, and their long-term impacts are still murky (Campante and Chor, 2012). Four years after the beginning of the Arab Spring, social unrest continues in places (Table 1) while countries in transition, including Egypt, Jordan, Libya, Morocco, and Tunisia, are in the midst of an economic downturn. Egypt, for example, is facing serious economic challenges and erosion in investor confidence, as social and political tensions remain high; Tunisia, where democratization is relatively advanced, continues to experience social disruption, which in turn affects economic activity. In Jordan and Morocco, while political transitions have advanced economic growth has been slow.

There is considerable empirical evidence that political instability is not conducive to economic growth (Alesina et al, 1996; Khandelwal and Roitman, 2013), to investment (Alesina and Perotti, 1996), or to price stability (Aisen and Veiga, 2006). Sea changes in political regimes in adjacent countries also generally affect trade patterns, but examining these effects is often difficult because of measurement problems. We look in particular at the impacts of the Arab Spring in North Africa and the Levant on international trade in air transportation services within the region. Air transportation, although a service industry has a clear measureable proxy for its supply, namely seats provided, and can act as a guide to the larger trade implications of macroeconomic changes.

Table 1. Main events of the Arab Spring

\begin{tabular}{lll}
\hline Country & Starting date & Notes \\
\hline Tunisia & 18 December 2010 & Government overthrown, 14 January 2011 \\
Algeria & 29 December 2010 & Ended, January 2012 \\
Jordan & 14 January 2011 & Ended \\
Oman & 17 January 2011 & Ended, May 2011 \\
Egypt & 25 January 2011 & Governments overthrown February 2011 \& \\
& & July 2013. Ongoing civil war \\
Yemen & 27 January 2011 & Governments overthrown February 2012 \& \\
& & January 2015. Ongoing civil war \\
Djibouti & 28 January 2011 & Ended, March 2011 \\
Somalia & 28 January 2011 & Ended \\
Sudan & 30 January 2011 & Ongoing \\
Iraq & 12 February 2011 & Ended January 2014 \\
Bahrain & 14 February 2011 & Ongoing \\
Libya & 17 February 2011 & Government overthrown, 23 August 2011 \\
Kuwait & 19 February 2011 & Ended, December 2012 \\
Morocco & 20 February 2011 & Ended, March/April 2012 \\
Mauritania & 25 February 2011 & Ended \\
Lebanon & 27 February 2011 & Ended, December 2011 \\
Saudi Arabia & 11 March 2011 & Ended
\end{tabular}


Syria 26 January $2011 \quad$ Ongoing

Iranian Khuzestan 15 April $2011 \quad$ Ended, 18 April 2011

We focus on a number of the larger countries in North Africa and the Levant, often ones that have traditionally had relatively large international air traffic flows, namely Egypt, Morocco, Tunisia, Algeria, Lebanon, Libya, and Jordan. Syria is excluded because of a lack of consistent data, especially on GDP, since the up-rising there, as are the Gulf States because, although Qatar and the United Arab Emirates have significant air transportation activities, most traffic is external to the MENA, and that within the region involves large amounts of feeder traffic into inter-continental routes rather than being internal to the MENA. We look at the short-term effects of the significant political changes that have occurred on airline capacity being offered within the region; longerterm impacts are only likely to be seen once the revolutions have died down and more permanent economic reforms are in place (Malik and Awadallah, 2013).

\section{The modeling framework}

We adopt a threshold modeling approach to distinguish ranges of values where the behavior predicted by the model varies in some important way, in this case after a major socio-economic change. The approach is widely used in toxicology, where the model for the effect of a drug may be that there is zero effect for a dose below a critical value, while an effect of some significance exists above that value. In our case, relatively stable political regimes and trade-links have potentially been changed after the Arab Spring. That such an effect has been present in a general sense can be seen in the time series data on airline seats provided between the targeted countries from the later 1990s (Figure 1).

For estimation we use a segmented regression approach. This involves partitioning the independent variable at breakpoints into intervals and a separate line segment is fit to each interval. Here it is used when examining for different relationships between variables in regions under review.

The analysis initially looks each country separately. While the region has a population of about 350 million, which share a common language and culture, and has a long trading tradition, trade linkages between Arab countries is weak (Sui and Walkenhorst, 2010), with few countries seeing neighbors as natural trading partners. Additionally, efforts to develop trade agreements have largely failed (Nugent and Yousef, 2005; Momani, 2007). The airline seats offered by each country to others in the sample are seen in Figure 1. These only reflect supply conditions for air service trade; there is no available data regarding passengers carried.

We adopt a simple linear model:

$S E A T_{\mathrm{it}}=\alpha+\beta_{1} G D P_{\mathrm{it}}+\beta_{2}\left(C O N F L . G D P_{\mathrm{it}}\right)+\beta_{3} W P A X_{\mathrm{t}}+\varepsilon_{\mathrm{it}}$

where; SEAT is the annual number of seats on flights departing/arriving in country $i$ to/from other sampled MENA countries in year $t, G D P$ is the annual national income in 
current prices, CONFL is a dummy equal to 1 from year 2011, and $W P A X$ is the annual number of global air transportation passengers. Ordinary least squares is used for estimation. Given the short period under review, 1997 to 2013, and that the existing supply of seats is well below levels found in more developed European markets, a linear approximation, rather than some sigmoid function moving towards an asymptote, provides an acceptable approximation.

Data for the annual seats provided between each country and others in the data set is taken from the Official Airline Guide (www.oag.com), and those for GDP from World Bank sources (http://data.worldbank.org/indicator/NY.GDP.MKTP.CD). From Table 1 we see that the MENA region began to experience serious political unrest in December 2010, that became more extreme in 2011; hence the use an interactive dummy variable with GDP from 2011 to examine whether established links between national GDP growth and growth in airline seats supplied to and from a country were disrupted. The World Passengers variable is included to capture background trends in the global aviation market that affect all carriers; it provides a ceteris parabus backdrop. For example it captures the impact of the 2008 Great Recession on all air travel as seen in Figure 1.

\section{Results}

The main results for the individual countries under study are seen in Table 2. As may be expected from relatively short data runs the overall fits of the models are high, and in line with most previous analysis of national airline markets (Boeing Commercial Airplanes (2015), GDP generally comes out positive and highly significant. By and large the coefficient capturing broader trends in the aviation market in which the MENA nations operate, is as anticipated positive and often highly significant. ${ }^{1}$

Table 2. Regression estimates by country

\begin{tabular}{lrrrrr}
\hline Country & \multicolumn{1}{c}{$\alpha_{1}$} & \multicolumn{1}{c}{$\beta_{1}$} & \multicolumn{1}{l}{$\beta_{2}$} & \multicolumn{1}{l}{$\beta_{3}$} & $\mathrm{R}^{2}$ \\
& & & & & \\
\hline Algeria & 34,156 & $4.84 \mathrm{e}-07$ & $-2.04 \mathrm{e}-07$ & 0.0002 & 0.849 \\
Egypt & $-1,191,637 * * *$ & $5.61 \mathrm{e} 06^{* * *}$ & $-1.69 \mathrm{e}-06 * *$ & $0.0010^{* * *}$ & 0.967 \\
Jordan & 379,663 & $0.00004 * * *$ & $-1.07 \mathrm{e}-06$ & $7.08 \mathrm{e}-06$ & 0.937 \\
Lebanon & 129,276 & $0.00002^{* * *}$ & $1.15 \mathrm{e} 06$ & 0.00009 & 0.946 \\
Libya & $-1,875,465 * * *$ & $6.33 \mathrm{e}-06$ & $3.36 \mathrm{e}-06$ & $-0.0012^{* * *}$ & 0.849 \\
Morocco & $-162,532$ & $4.45 \mathrm{e}-06^{* * *}$ & $-7.89 \mathrm{e}-06$ & $0.0003 * * *$ & 0.978 \\
Tunisia & $-542,705$ & -0.00001 & $7.49 \mathrm{e}-06$ & 0.0010 & 0.825 \\
\hline
\end{tabular}

$* * *$ significant at $1 \% ; * *$ at $5 \%$; at $10 \%$,

In terms of our specific interest, the implications of the Arab Spring, the interactive CONFL.GDP parameter is never significant, and its signs vary between negative and positive, although the majority is the former. The countries that have positive signs, however, include the Lebanon, which, although never really a politically stable country,

\footnotetext{
${ }^{1}$ Looked at from an investor's perspective, the $W P A X$ is picking up the $\alpha$ risk associated with the overall aviation market, and GDP the $\beta$ risk for the airline market of the particular country concerned.
} 
underwent little by way of major abnormal trauma between 2011 and 2013. The situations regarding Libya and Algeria are more difficult to explain.

Regarding Libya, while its revolution was violent, by October 2012, the economy had recovered from the conflict, with oil production returning to near normal levels partly due to the return of Total, Eni, Repsol, Wintershall, and Occidental. Algeria's Spring came early and, as we saw in Table 1, we effectively over by the end of 2011. In none of these cases do these facts, however completely explain the positive signs found given that seats reflects the states of markets at either end of routes and not just the country being directly analyzed.

There have been a number of, mainly ineffectual efforts to reduce institutional impediments to trade between the MENA nations of which the Arab Maghreb Union (AMU) is the oldest of any substance. ${ }^{2}$ It is a trade agreement established in 1989 aimed at economic and political unity among Arab countries of the Maghreb in North Africa, namely Algeria, Libya, Mauritania, Morocco and Tunisia. If there has been any genuine progress towards economic integration between AMU members one would anticipate a higher degree of resilience in their overall interactions. To test this we use panel data and introduce a dummy variable taking the value 1 for the $A M U$ members in the data set. The results, based a random effect specification, are seen in Equation 2. ${ }^{3}$

$$
\begin{array}{r}
S E A T=-562,886^{* * *}+1.62 \mathrm{e}-06 G D P^{* *}-5.18 \mathrm{e}-07 C O N F L . G D P+0.0008 W P A X^{* * *}- \\
316481 A M U^{* * *}- \\
\mathrm{R}^{2} \mathrm{~s}: \text { within }=0.668 ; \text { between }=0.305 ; \text { overall }=0.581
\end{array}
$$

The CONFL.GDP interactive variable takes a negative sign indicating that the conflicts in the regional had adverse, although not significant, implications for overall air transportation service supply. The $A M U$ variable is also negative but highly significant suggesting that whatever effects the regional economic union may have had in other sectors, it has done little to support the airline sector during and after the Arab Spring.

\section{Conclusions}

Obtaining reliable economic data during periods of unrest and conflict is inevitably challenging. The use of a physical measure that is relatively easy to compute and hard to manipulate can provide some indications of the effects of such conflicts on trade. What we find is that, there is some weak evidence that trades in air services between the MENA countries we have examined have been adversely affected in the short-term by the Arab Spring. In some cases, however, where there are specific distinctions in the nature of the changes to national political economies, the reverse is the case. There is no evidence that the major economic union in the region, the AMU, has provided any protection to the airline market during the upheavals that have occurred.

\footnotetext{
${ }^{2}$ The other agreements include the Arab Common Market, the United Arab Republic, Federation of Arab Republics, Arab Cooperation Council, the Greater Free Arab Free Trade Agreement, and the Agadir Agreement.

${ }^{3}$ The model was also tested using country fixed effects, but collinearity meant that AMU was not estimated.
} 


\section{References}

Aisen, A. and Veiga, F.J. (2006) Does political instability lead to higher inflation? A panel data analysis, Journal of Money, Credit, and Banking, 38, 1379-1389.

Alesina, A., and Perotti, R. (1996) Income distribution, political instability and investment, European Economic Review, 40,1203-1228.

Alesina, A., Ozler, S., Roubini, N. and Swagel, P. (1996) Political instability and economic growth, Journal of Economic Growth, 1, 189-211.

Boeing Commercial Airplanes (2015) Current Market Outlook 2014-2033, Boeing Commercial Airplanes, Seattle.

Campante, F.R. and Chor, D. (2012) Why was the Arab World poised for revolution? Schooling, economic opportunities, and the Arab Spring, Journal of Economic Perspectives, 26, 167-88.

Khandelwal, P. and Roitman, A. (2013) The Economics of Political Transitions: Implications for the Arab Spring, IMF Working paper, WP/13/69, Washington, DC.

Malik, A. and Awadallah, B. (2013) The economics of the Arab Spring, World Development, 5, 296-313.

Momani, B. (2007) A Middle East Free Trade Area: economic interdependence and peace considered, The World Economy 30, 1682-1700

Nugent, J.B. and Yousef, T. (2005) Does MENA Defy Gravity? How MENA has Performed in its Intraregional, EU and Other Trade. EUI Working Paper 2005/26, Florence.

Shui, L. and Walkenhorst, P. (2010). Regional integration: Status, developments, and challenges. In J. R. López-Cálix, P. Walkenhorst and D. Ndiamé (Eds.), Trade Competitiveness in Middle East and North Africa: Policies for Export Diversification, World Bank, Washington, DC. 
Figure 1. Combined outbound and inbound airline seats from/to selected MENA countries and other in the data set.

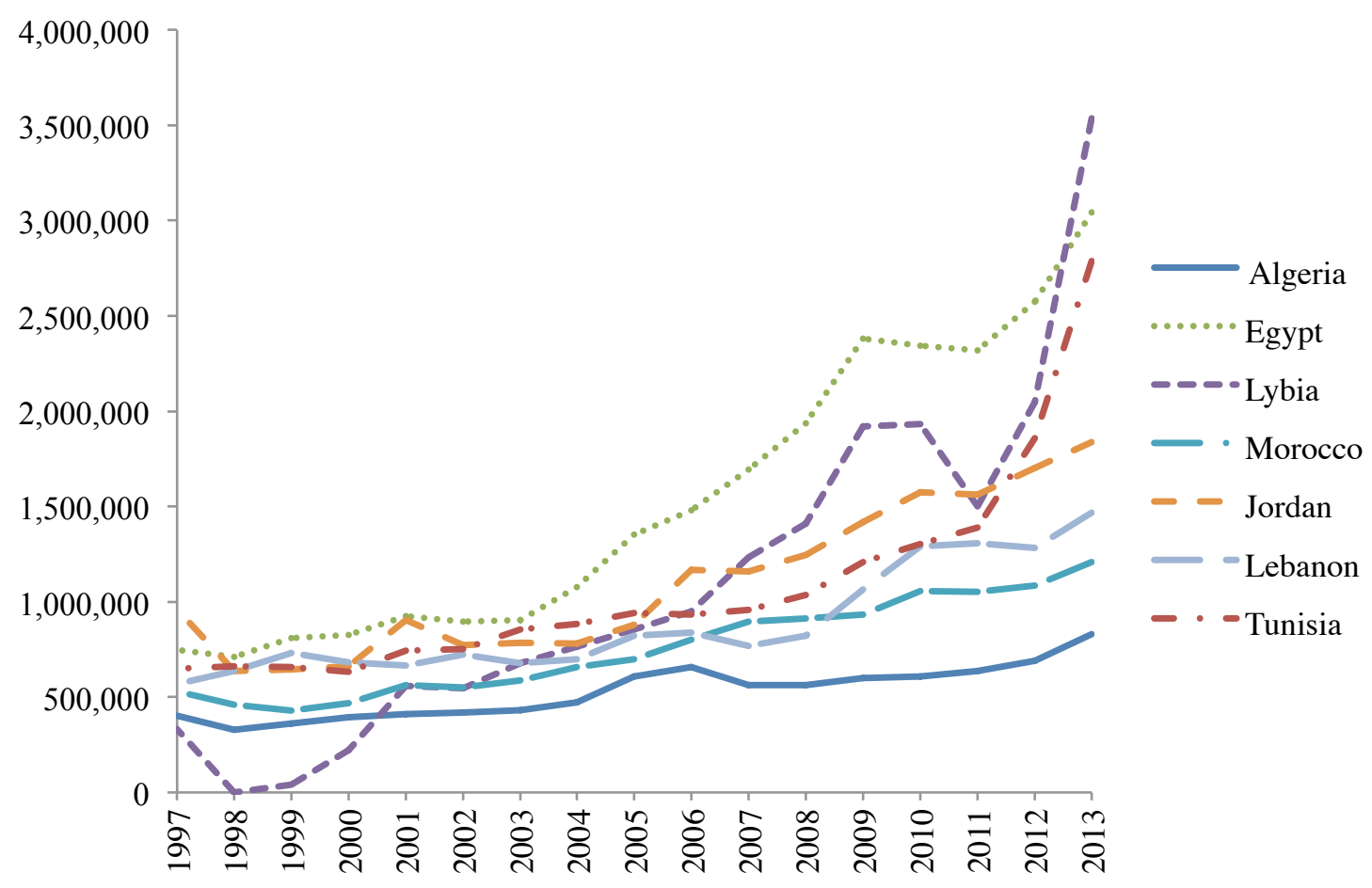

